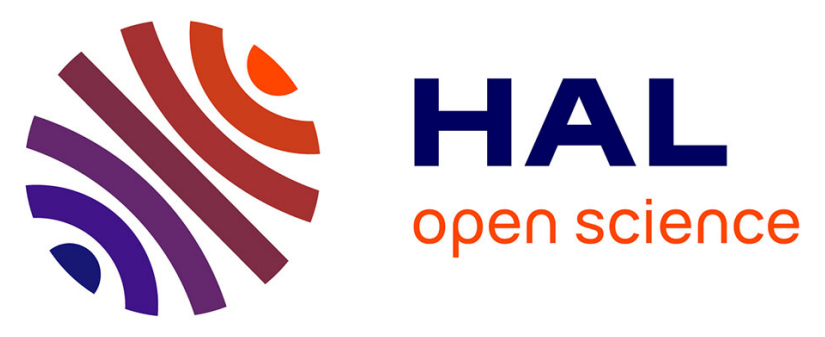

\title{
ATOL and EOL ontologies, steps towards embryonic phenotypes shared worldwide?
}

\author{
Isabelle Hue, Jérôme Bugeon, Olivier Dameron, Alice Fatet, Catherine \\ Hurtaud, Léa Joret, Marie-Christine Meunier-Salaün, Claire Nédellec, \\ Matthieu Matthieu.Reichstadt@inrae.Fr Reichstadt, Jean Vernet, et al.
}

\section{To cite this version:}

Isabelle Hue, Jérôme Bugeon, Olivier Dameron, Alice Fatet, Catherine Hurtaud, et al.. ATOL and EOL ontologies, steps towards embryonic phenotypes shared worldwide?. 4. Mammalian Embryo Genomics Meeting, Université Laval. CAN., Oct 2013, Hilton Quebec City, Canada. 102 p., 10.1016/j.anireprosci.2014.06.013 . hal-01205091

\section{HAL Id: hal-01205091 \\ https://hal.science/hal-01205091}

Submitted on 3 Jun 2020

HAL is a multi-disciplinary open access archive for the deposit and dissemination of scientific research documents, whether they are published or not. The documents may come from teaching and research institutions in France or abroad, or from public or private research centers.
L'archive ouverte pluridisciplinaire HAL, est destinée au dépôt et à la diffusion de documents scientifiques de niveau recherche, publiés ou non, émanant des établissements d'enseignement et de recherche français ou étrangers, des laboratoires publics ou privés. 
during each of these critical events/steps is still unknown. Therefore, we aimed to examine the effect of alternative vivo/vitro culture conditions during main developmental stages on the transcriptome profile of bovine blastocysts. We have used state-of-the-art nonsurgical endoscopic flushing and transfer of early stage embryos to the bovine oviducts to produce two different sets of blastocysts (6 groups each) under alternative vivo/vitro culture conditions. For the first set, oocytes/embryos were produced in vitro and transferred to synchronized recipients at different time points (matured oocyte, fertilized oocyte, zygote, 4-cell, 16-cell and morula stage) then flushed out at day 7 blastocyst stage. For the second set, embryos were produced in vivo, flushed out at different time points (2-, 4-, 8-, 16-, 32-cell and morula stage) and cultured in vitro until day 7 blastocyst stage. Complete in vitro (IVP) and in vivo blastocysts were used as controls. Gene expression pattern between each blastocyst group and in vivo control group were compared using EmbryoGENE's bovine microarray over six replicates of each group. Results showed that oocyte origin critically determined the developmental rates and the ability of embryo to react with changing culture conditions. Transcriptome analysis indicated three time points: fertilization, embryonic genome activation (EGA) and blastocyst formation as the most critical stages affected by changing culture conditions from in vivo to in vitro or vice versa. Molecular mechanisms and pathways that are influenced by altered culture conditions were defined. These results indicate the critical stages of early bovine embryo which are sensitive to environmental factors during the course of development. This in turn will help to design new strategies to modify culture environment in stage specific manner for better developmental potential.

\section{http://dx.doi.org/10.1016/j.anireprosci.2014.06.012}

\section{ATOL and EOL ontologies, steps towards embryonic phenotypes shared worldwide?}

I. Hue ${ }^{1, *}$, J. Bugeon ${ }^{2}$, O. Dameron ${ }^{3}$, A.

Fatet $^{4}$, C. Hurtaud ${ }^{5}$,

L. Joret ${ }^{2}$, M.C. Meunier-Salaün ${ }^{5}$, C.

Nédellec ${ }^{6}$,

M. Reichstadt ${ }^{7}$, J. Vernet ${ }^{7}$, P.Y. Le Bail ${ }^{2}$

${ }^{1}$ INRA, UMR 1198 BDR, 78352

Jouy-en-Josas, France

2 INRA, UR 1037 LPGP, Campus de Beaulieu,

35042 Rennes, France

${ }^{3}$ INSERM U 936, Université de Rennes I,

35000 Rennes, France

${ }^{4}$ INRA, UR 0085 PRC, 37380 Nouzilly, France

${ }^{5}$ INRA-AgroCampus, UMR 1348 PEGASE,

35590 St-Gilles, France

${ }^{6}$ INRA, MIG, 78352 Jouy-en-Josas, France

${ }^{7}$ INRA, UMRH 1213, 63122 Saint Genès

Champanelle, France

The development and the use of ontologies contribute to a better organization and use of the huge amount of knowledge available in biology, but could even contribute better when used worldwide to share common bases when publishing morphological data or molecular phenotypes (Gene Ontology, for example). We have built ATOL (http://www.atol-ontology.com) for "Animal Trait Ontology for Livestock" that is devoted to the definition and organization of phenotypic traits of farm animals including fish, birds and mammals. Given that phenotypes result from the action of both the genotype and the environment, a precise description of the animal rearing environments is critical. We thus created EOL for "Environment Ontology for Livestock", to describe the livestock systems and the rearing conditions in a generic manner. We could however extend that for in vitro and in vivo produced embryos to define the culture media, the origins of the gametes or the statuses of the dams that carry the embryos (breed, parity, energy balance, farming conditions). The combination of embryonic traits (in ATOL) and rearing conditions (in EOL) would enable a standardized and precise annotation of phenotypic databases linked to explicit metadata. Such ontologies also appear critical resources for automated semantic analyses that retrieve accurate information from relevant scientific or technical documents. Moreover, integrative and systemic approaches based on modelling would gain from a formal representation of knowledge that could then be automatically processed. The context and the content of both ontologies, as well as their putative application to embryo production and development, will be presented.

http://dx.doi.org/10.1016/j.anireprosci.2014.06.013

\section{Detection of genes associated with developmental competence of bovine oocytes, quantification of transcript levels before and after oocyte maturation}

\author{
D. Pesanova ${ }^{1}$, L. Nemcova ${ }^{1}$, K. \\ Vodickova-Kepkova ${ }^{1}$, \\ P. Vodicka ${ }^{1,3}$, M. Jeseta ${ }^{2}$, M. \\ Machatkova $^{2}$, J. Kanka ${ }^{1, *}$ \\ ${ }^{1}$ Institute of Animal Physiology and \\ Genetics, Academy of Sciences of the Czech \\ Republic, Libechov, Czech Republic \\ 2 Veterinary Research Institute, Brno, Czech \\ Republic \\ ${ }^{3}$ Department of Neurology, Massachusetts \\ General Hospital and Harvard Medical \\ School, Charlestown, MA, USA
}

Developmental competence of oocytes is acquired progressively during folliculogenesis and is linked to follicular size. It has been documented that oocytes originated from larger follicles show greater ability to develop to the blastocyst stage. The differences in cytoplasmic factors like mRNA transcripts could explain differences in oocyte developmental potential. In order to characterize differences in gene expression profiles of oocytes either from medium (MF, 6-10 mm) or small (SF, 2-5 mm) follicles 